Buca Eğitim Fakültesi Dergisi, 2021, Sayı 51, s. 97-118

Araştırma Makalesi
The Journal of Buca Faculty of

Education, 2021, Issue 51, p. 97-118

Original Research

\title{
3D Stratejisi Öğretiminin Öğrenme Güçlüğü Olan Öğrencilerin Okuduğunu Anlama Becerilerine Etkisi
}

\section{Effectiveness of TWA Strategy Instruction on Reading Comprehension Performances of Students with Learning Disabilities}

\author{
Burcu KILIÇ TÜL $\ddot{U}^{1}$, Ahmet Bilal ÖZBEK ${ }^{2}$, Cevriye ERGÜL ${ }^{3}$
}

\begin{abstract}
${ }^{I}$ Sorumlu Yazar, Öğr. Gör. Dr., Özel Eğitim Bölümü, Eğitim Bilimleri Fakültesi, Ankara Üniversitesi,Türkiye,tulu@ankara.edu.tr, (https://orcid.org/0000-0002-9623-8392)

${ }^{2}$ Araş. Gör. Dr., Özel Eğitim Bölümü, Eğitim Fakültesi, Ankara Üniversitesi, Türkiye, bilal.ozbek@deu.edu.tr, (https://orcid.org/0000-0002-0200-4932)

${ }^{3}$ Prof. Dr., Özel Eğitim Bölümü, Eğitim Bilimleri Fakültesi, Ankara Üniversitesi, Türkiye, cergul@ankara.edu.tr, (https://orcid.org/0000-0001-6793-6469)
\end{abstract}

\section{ÖZ}

Okuduğunu anlama problemleri öğrencilerin tüm akademik alanlardaki performanslarını ve eğitim hayatlarını olumsuz olarak etkileyen bir durumdur. Bu araştırmanın amacı kendini düzenleme stratejileri gelişimi (KDSG) modeline göre yapılan Okuma Öncesinde-Sırasında-Sonrasında Düşün (TWA) 3D strateji öğretiminin öğrenme güçlüğü olan öğrencilerin bilgi veren metinlerde okuduğunu anlama performanslarına etkisini belirlemektir. Bu amaçla öğrenme güçlüğü tanısı almış 4. sınıfa devam eden dört erkek öğrenci ile çalışılmıştır. Araştırma tek denekli deneysel desenlerden denekler arası çoklu başlama düzeyi modeline göre yürütülmüştür. Araştırmanın sonucunda KDSG modeline göre yürütülen 3D strateji öğretiminin öğrencilerin metni anlama soruları ve metni anlatma performansları üzerinde etkili olduğu görülmüştür. İzleme oturumlarında da öğrencilerin kazanımlarını büyük ölçüde korudukları belirlenmiştir. Elde edilen veriler KDSG modeline göre yapılan strateji öğretiminin öğrencilerin okuduğunu anlama becerilerinde etkili olduğunu göstermektedir. Bulgular alan yazın temelinde tartışılmıştır.

Anahtar Kelimeler: Okuduğunu anlama, öğrenme güçlügü, kendini düzenleme stratejileri, bilgi veren metinler, okuma stratejileri.

\begin{abstract}
Reading comprehension problems negatively affect students' academic success. The aim of this study is to determine the effectiveness of think before-while-after (TWA) 3D strategy instruction on reading comprehension performances of students with learning disabilities in informative texts. Four 4 th grade male students participated in the study. The research was carried out according to the multiple-baseline across participants, which is one of the single subject experimental designs. As a result of the research, it has been observed that 3D strategy instruction conducted according to SRSD model has an effect on students' comprehension performances. Participants maintained their gains in follow up sessions after intervention phase. Findings discussed further.
\end{abstract}

Keywords: Reading comprehension, learning disability, self-regulation strategies, descriptive texts, comprehension strategies. 


\section{GİRIŞ}

Okuma, sözcükleri doğru çözümleyerek akıcı okumayı ve bu okunanları sözcük, cümle ve metin düzeyinde anlamayı gerektirmektedir (Jones, 2010). Okuma, karmaşık, bilişsel ve amaçlı bir süreçtir (Kendeou, van den Broek, Helder ve Karlsson, 2014) ve ilerleyen y1llardaki tüm akademik becerilerin temelini oluşturur (Entwisle, Alexander ve Olson, 2005; Kamil, 2003). Bu nedenle ilkokulun temel amaçlarından biri öğrencilere okumayı öğretmektir. Okulun ilk yıllarında okumayı öğretmeye yönelik çalışmalara ağırlık verilirken ilerleyen yıllarda okuduğunu anlama üzerinde daha fazla çalışılmakta ve yeni bilgiler edinmede okuma bir araç olarak kullanılmaktadır (Wanzek ve diğ., 2013). Okuma öğretiminin ve yapılan çalışmaların nihai hedefi çocuklara okuduğunu anlama becerilerini kazandırmaktır (Mahdavi ve Tensfeldt, 2013).

Grabe ve Stoller (2002) okuduğunu anlamayı karmaşık, hızlı, birçok bilişsel süreci içeren üst düzey bir beceri olarak ifade etmişlerdir. Okuduğunu anlama için gereken bu bilişsel süreçler ikiye ayrılır (Kendeou ve diğ., 2014). Bunlardan ilki doğru ve akıcı okuma, yeterli sözcük bilgisine sahip olma, dili anlama gibi beceriler iken (Kirby ve Savage, 2008; Wolf 1997); ikincisi yeni bilgilerle eski bilgileri birleştirebilme, çıkarım yapma, bellek ve strateji kullanımına ilişkin becerilerdir (Graham ve Bellert, 2005; Kendeou ve Trevors, 2012; Sesma, Mahone, Levine, Eason ve Cutting, 2009; van den Broek ve Kremer, 1999). Sözcük çözümleme gibi okuduğunu anlamada etkili olan ilk süreçler okulun ilk yıllarında hızlı bir gelişim gösterir ve öğrenciler bu becerilerde oldukça hızlı otomatikleşirler (Kendeou, Papadopoulos ve Spanoudis, 2012). Ancak, okuduğunu anlamada etkili olan ikincil süreçler daha yavaş geliştirdiğimiz becerilerdir (Luna, Garver, Urban, Lazar ve Sweeney, 2004; Perfetti ve Hart, 2002). Bazı öğrenciler ikincil süreçleri her zaman iyi bir şekilde yönetememekte, bu bileşenlerden bir ya da birkaçında problemler yaşamakta ve okuduğunu anlamakta zorlanmaktadırlar (Tunmer, 2008). Bu öğrenciler genellikle öğrenme güçlüğü ile tanılanmakta ya da ilerleyen akademik hayatları boyunca okuma güçlükleri yaşamaktadırlar (Lyon, 1998). Farklı çalışmalarda özgül öğrenme güçlüğü, özel öğrenme güçlüğü olarak da ifade edilen tanı grubu için bu çalışmada öğrenme güçlüğü terimi kullanılmıştır.

Okuma güçlüğü ya da öğrenme güçlüğü olan pek çok öğrencinin okuma problemleri genellikle çözümlemede ve akıcı okumada yaşadıkları problemlerle ilişkilendirilmiştir. Ancak yapılan çalışmalar bazı öğrencilerin çözümleme problemi yaşamadıkları ya da yeterli okuma akıcılığına sahip oldukları halde okuduğunu anlamada problemler yaşadıklarını göstermektedir (Cain ve Oakhill, 2007; Hulme ve Snowling, 2011; Nation, 2005). Boylamsal bir araştırmada çözümleme becerilerinin ve okuma akıcılığının 2. sınıftan sonra öğrencilerin okuduğunu anlama performanslarını yordama düzeylerinin düştügünü göstermektedir (Torppa ve diğ, 2016). İkincil süreçlerden kaynaklanan okuduğunu anlama problemleri yaşayan bu öğrencilerin okurken önemli bilgileri ayırt etmek (Dermitzaki, Andreou ve Paraskeva 2008), metin yapısını anlamak (Gersten, Fuchs, Williams ve Baker, 2001) gibi problemlerinin yanı sıra okuma öncesinde, sirasında ve sonrasında kendilerini izlemede problem yaşadıkları ifade edilmektedir (Dabarera, Renandya ve Zhang, 2014). Başka bir deyişle, okuduğunu anlamak için gerekli bilişsel ve üstbilişsel stratejileri kullanmakta sınırlılıklar yaşamaktadırlar (Mason, Meadan, Hedin ve Corsa, 2006). Dolayısıyla okuma sırasında kendilerini izlemekte, kendilerini okuma amaçlarına yönelik yönlendirmekte, amaçlarını kontrol etmekte ve bu yönde kendilerini düzenlemekte zorlanırlar (Bender, 2002). Bu açıdan üstbilişsel stratejilerin okuduğunu anlama becerileri için kritik öneme sahip olduğu ve okuma ya da öğrenme güçlüğü olan çocukların okuma sırasında üstbilişsel stratejileri kullanamadıkları ifade edilmektedir (Williams ve Atkins, 2009).

Okuduğunu anlama problemlerinin oldukça sık görüldüğ̈̈ öğrenme güçlüğü olan öğrencilerin iyi okuyucularla karşılaştırıldığı çalışmalarda bu öğrencilerin strateji kullanmadıkları, stratejilere ilişkin bilgi düzeylerinin yetersiz olduğu ya da stratejileri ne zaman ve nasıl kullanacaklarını bilmedikleri görülmüştür (Dermitzaki ve diğ., 2008). Ek olarak, araştırmalar öğrenme güçlüğü olan öğrencilerin bu stratejileri kendi kendilerine öğrenemediklerini göstermektedir (Girli ve Öztürk, 2017). Öte yandan bilişsel ve üstbilişsel strateji öğretimi 
yapıldığında öğrenme güçlüğ̈̈ olan öğrencilerin okuduğunu anlama becerilerinde gelişme görüldügü belirtilmektedir (Forness, Kavale, Blum ve Lyod, 1997; Gajria, Jitendra, Sood ve Sacks, 2007; Gersten ve diğ., 2001; Kim, Linan-Thompson ve Misquitta, 2012; Swanson, 1999).

Öğrenme güçlüğ̈̈ olan öğrencilerin okuduğunu anlama becerilerinin geliştirilmesine yönelik çalışmalar incelendiğinde farklı stratejilerin kullanıldığ 1 görülmektedir. Bunlardan bazıları, soru sorma, özetleme, ön bilgileri harekete geçirme, ana fikir bulma gibi stratejilerdir. Bunların pek çoğunda yapılan uygulamaların okuma öncesi, sırası ve sonrasındaki tüm süreci kapsayacak şekilde planlandığı dikkati çekmektedir (Pressley, 2000; Swanson ve diğ., 1999; Tracey ve Morrow, 2002). Bu kapsamda siklıkla kullanılan stratejilerden biri de Okuma Öncesinde-Sırasında-Sonrasında Düşün (3D)' (Think-Before-While-After, TWA) olarak ifade edilen ve dokuz adımda uygulanan 3D stratejisidir (Baker, Gertsen ve Scanlon, 2002). 3D farkl1 staratejilerin okuma öncesinde sırasında ve sonrasında birlikte kullanıldığı bir yöntemdir. Okuma öncesinde öğrenciye yazarın amacı hakkında düşünerek önbilgilerini, konu hakkında neler bildiğini ve neler öğrenmek istediğini düşünerek önceki bilgilerini harekete geçirmeleri öğretilmektedir. Okuma sırasında öğrenci, okuma hızını ayarlaması, bilgiyi edinmesi ve anlamadığını farkettiği bölümleri tekrar okuması konusunda teşvik edilmektedir. Okuma sonrasında ise metnin anafikri, metindeki bilgilerin özeti ve metinden neler öğrendiği üzerine düşünmesi istenmektedir.

Okuduğunu anlama becerilerinin desteklenmesinde kullanılan stratejilerin öğrencilere öğretilmesinde ise sesli düşünme, karşılıklı öğretim, metin yapısı öğretimi ve kendini düzenleme strateji öğretimi gibi yöntemlerden faydalanılmaktadır (Duke ve Pearson, 2008; Watson, Gable, Gear ve Hughes, 2012). Bu kapsamda kullanılan yöntemlerden biri de Kendini Düzenleme Stratejileri Gelişimi- KDSG (Self Regulated Strategy Development- SRSD) yaklaşımıdır. Bu yaklaşım Graham, Harris, McHartur ve Schwartz (1991) tarafindan, bilişsel strateji öğretimine alternatif olarak ve öğrencilerin üstbilişsel becerilerini desteklemek amaciyla geliştirilmiştir. $\mathrm{Bu}$ yaklaşımın amacı okuma-yazma, matematik, ödev yapma, çalışma gibi alanlarda öğrencilerin bağımsızlaşmasını sağlamaktır. KDSG modelinin aşamaları önbilgilerin geliştirilmesi, tartışma, model olma, ezberleme, destekleme ve bağımsız uygulamalardır (Mason, Harris ve Graham, 2013). Süreç öğretmen kontrolü ile başlamakta ve öğrencinin ihtiyacina uygun düzeyde öğretimsel destekler sunulmaktadır. Öğrencinin aktif olarak yer aldığı bu süreçte aşamalı olarak sorumluluk öğrenciye devredilmektedir (Graham ve Harris, 2003). Bir önceki paragrafta anlatılan okuduğunu anlama becerilerinin desteklenmesinde kullanılan stratejilerin ve KDSG gibi yöntemlerin birlikte kullanıldığı müdahale programlarının öğrenme güçlüğ̈̈ olan öğrencilerin okuduğunu anlama performansları üzerinde etkili sonuçlar verdiği görülmektedir (Jitendra, Cole, Hoppes ve Wilson, 1998; Lederer, 2000; Malone ve Mastropieri, 1992). Nitekim okuduğunu anlamaya yönelik stratejilerin KDSG öğretim modeli basamaklarına göre çalışıldığ çalışmalarda öğrenme güçlüğü olan öğrencilerin okuduğunu anlama performanslarında önemli gelişmeler sağlandığı görülmektedir (Mason, 2004; Mason, Hickey Snyder, Jones ve Kedem, 2016). 3D strateji öğretiminin KDSG öğretim modeli temelinde yapıldığı çalışmalar da buna bir örnektir (Jitendra ve diğ., 2000; Mason ve di ̌̆., 2006).

Ulusal alanyazında farklı özelliklerdeki öğrencilerin okuduğunu anlama becerilerini geliştirmeye yönelik çalışmaların yapıldığı görülmektedir (Aktaş, 2015; Atik-Çatak, 2006; Coşkun, 2011; Cora-İnce, 2007). Bu çalışmalarda normal gelişim gösteren öğrencilerin (Coşkun, 2011; Özdemir, 2017), öğrenme güçlüğü olan öğrencilerin (Deniz ve Aslan, 2020; Firat, 2019), zihinsel yetersizliği olan öğrencilerin yer aldıkları görülmektedir (Cora-İnce, 2007; Duman, 2006; Güldenoğlu ve Kargın, 2012). Özel gereksinimli öğrencilerle yaplmış olan çalışmalarda okuduğunu anlama becerilerinin strateji öğretimi yapılarak gerçekleştirildiği sınırlı sayıda çalışma bulunmaktadır (Bilgi ve Özmen, 2014; Güldenoğlu ve Kargın, 2012; Güler ve Özmen, 2010). Bu çalışmalardan biri olan Güler'in çalışmasında okuma öncesi, sırası ve sonrası okuduğunu anlama stratejilerinden hangisinin/hangilerinin hafif düzeyde zihinsel yetersizliği olan öğrencilerin okuduğunu anlama becerilerinde etkili olduğu araştırılmıştır. Öyküleyici 
metinlerin kullanıldığ 1 bu çalışmada alanyazına benzer şekilde bu üç tekniğin birlikte kullanılmasının okuduğunu anlama performansının arttırılmasında en etkili yol olduğu sonucuna ulaşılmıştır. Güldenoğlu ve Kargın'ın çalışmasında zihinsel yetersizliği olan öğrencilerin okuduğu anlama becerileri üzerinde karşılıklı öğretim yönteminin etkililiği incelenmiştir. Öyküleyici metinler üzerinde yürütülen çalışmalar sonucunda karşılıklı öğretim yönteminin hafif zihinsel yetersizliği olan öğrencilerin okuduğunu anlama becerilerileri üzerinde etkili olduğu belirlenmiştir. Bir diğer çalışmada ise uyarlanmış çok öğeli bilişsel strateji öğretiminin hafif düzeyde zihinsel yetersizliği olan öğrencilerin bilgi veren metinlerde okuduğunu anlama performansları üzerindeki etkisi incelenmiştir (Bilgi ve Özmen, 2014). Çalışmanın sonucunda okuma öncesinde, sırasında ve sonrasında kullanılan çok öğeli bilişsel strateji öğretiminin öğrencilerin okuduğunu anlama perormansları üzerinde etkili olduğu görülmüştür.

Ulusal alanayazında öğrenme güçlüğü olan öğrencilerin okuduğunu anlama performanslarının geliştirilmesine yönelik hikâye haritası yönteminin (Deniz ve Aslan, 2020), sesli düşünme yönteminin (Uçar-Rasmussen ve Cora-İnce, 2017), ana fikir belirleme stratejisi öğretiminin (İlter, 2018) etkisinin incelendiği çalışmaların yapıldığı görülmektedir. Strateji öğretimi araștırmaları açısından ele alındığında Fırat ve Ergül'ün (2020) 3D stratejisinin öğrenme güçlüğü olan öğrencilerin bilgi veren metinlerdeki okuduğunu anlama becerilerine etkisini inceledikleri çalışma ön plana çıkmaktadır. Araştrımada 3D stratejisi doğrudan öğretim yoluyla öğrencilere öğretilmiş ve ek olarak metin yapısı öğretimi yapılmıştır. Araştırma sonucunda 3D stratejisinin öğrencilerin tanımsal türdeki bilgi veren metinleri anlamalarına katkı sağladığ 1 belirlenmiştir. Ulusal alanyazın incelendiğinde öğrenme güçlüğü olan öğrencilerin okuduğunu anlama becerileri üzerinde strateji öğretiminin etkililiğini inceleyen başka bir çalışmaların sayısının sınırlı olduğu görülmektedir. Bilişsel ve üstbilişsel strateji öğretiminin öğrenme güçlüğü olan öğrencilerin okuduğunu anlama becerilerinin desteklenmesinde etkisinin açık bir şekilde ortaya konulması ve alanda çalışan öğretmenlere yönelik rehberlik edilmesi açısından yeni çalışmaların yapılması büyük önem taşımaktadır. Bu nedenle bu araştırmada KDSG modeline göre yürütülen 3D strateji öğretiminin öğrenme güçlügü olan öğrencilerin bilgi veren metinlerde okuduğunu anlama becerilerine etkisini belirlemek amaçlanmıştır. Elde edilen bulguların ileri araştırmalara ve uygulamalara katkı sağlayacağı düşünülmektedir.

\section{YÖNTEM}

\subsection{Araştırmanın Deseni}

$\mathrm{Bu}$ araştırma tek denekli deneysel araştırma modellerinden denekler arası çoklu başlama düzeyi modeline göre yürütülmüştür. Bu modele göre, eş zamanlı olarak tüm deneklerle başlama düzeyi değerlendirmeleri yapılır. Birinci denekte kararlı veri elde edilince bağımsız değişkenin uygulamasına geçilir. Bu sırada diğer denekler ile başlama düzeyi değerlendirmelerine devam edilir. Birinci denekte ölçüt karşılanınca, ikinci denekte uygulamaya başlanır. Bu işlemler diğer denekler için de tekrarlanır (Alberto ve Troutman, 2009). Bu araştırma için ölçüt, öğrencilerin metni anlama testlerinde iki oturum üst üste 10 sorudan 7'sini doğru yanıtlaması olmuştur. Araştırmanın deneysel süreci Horner ve diğerleri (2005) ve Gersten ve diğerleri (2005) tarafından tek denekli deneysel araştırmalar için önerilen kalite göstergeleri dikkate alınarak planlanmıştır. Kalite göstergeleri katılımcılara ilişkin ayrıntılı bilgi verilmesi, denek seçim kriterlerinin tanımlanması, bağımlı değişkenin açık bir şekilde tanımlanması, bağımlı değişkenin farklı zamanlarda tekrarlı ölçümlenmesi, değerlendirmelere ilişkin uygulama güvenirliği ve gözlemciler arası güvenirlik hesaplaması yapılması, bağımsız değişkenin açık bir şekilde tanımlanması ve uygulanmasına ilişkin uygulama güvenirliğinin belirlenmesi, başlama düzeyinde tekrarlı ölçüm yapılması ve açık bir şekilde betimlenmesi, müdahale sürecinde en az üç veri noktasında deneysel etki gösterilmesi ile iç geçerlik sağlanması, benzer etkinin farklı ortam, materyal ya da katılımcılar ile görülerek dış geçerlik sağlanması ve sosyal olarak önemli bir bağımlı değişkenin 
ele alınması ile sosyal geçerlik kriterinin sağlanması olarak sıralanabilir (Horner ve diğ., 2005). Araştırmanın planlama aşamasında bu ilkeler göz önünde bulundurulmuştur.

\subsection{Katılımcilar}

Çalışmaya dördüncü sınıfa devam eden dört öğrenci katılmıştır. Katılımcıların belirlenmesi aşamasında öncelikle İzmir ili Buca ve Gaziemir ilçelerinde yer alan özel özel eğitim ve rehabilitasyon merkezleri ile görüşülmüştür. İlk aşamada belirlenen 17 öğrenci içerisinden ön değerlendirmeler yapılarak dört öğrenci çalışmaya dâhil edilmiştir. Belirlenen öğrencilerin ailelerinden aydınlatılmış onam formu ile bilgilendirmeler yapılarak izin alınmıştır. Katılımcıların belirlenmesinde bazı kriterler dikkate alınmıştır. Bunlar; öğrenme güçlüğü tanısı almış olmak, dördüncü sınıfa devam etmek, sınıf tekrarı yapmamış olmak, öğrenme güçlüğüne eşlik eden bir tanısı bulunmamak, daha önce bir strateji öğretimi müdahalesinde yer almamış olmak, ön değerlendirmelerde bir dakikada en az 45 sözcük okuma akıcıllğı göstermek ve çoktan seçmeli testten en çok dört soruya doğru yanıt verebilme kriterleridir.

Çalışmada yer alan birinci denek Mazhar, 9 yaş 3 aylıktır ve ikinci sınıfa devam ederken öğrenme güçlüğü tanısı almıştır. Mazhar ön değerlendirmede dakikada 47 sözcük okuma akıc1lığ 1 ve çoktan seçmeli testte 3 doğru yanıt performansı göstermiştir. Mazhar iki yıldır bir özel özel eğitim rehabilitasyon merkezinde özel eğitim destek hizmetlerinden yararlanmaktadır. Daha önce okuduğunu anlama stratejisi öğretimi çalışılmadığı öğretmeni tarafindan bildirilmiştir. İkinci denek Fuat 9 yaş 8 aylık, ikinci sınıfın sonunda öğrenme güçlüğü tanısı almış ve bir buçuk yıldır bir özel özel eğitim rehabilitasyon merkezinde özel eğitim destek hizmetlerinden yararlanan bir öğrencidir. Fuat ön değerlendirmede 52 sözcük okuma akıcıllğı ve dört doğru yanıt performans1 göstermiştir. Fuat için yapılan çalışmaların daha çok matematik dersine odaklı olduğu ve okuma akıcılığı çalışmalarının yapıldığı öğrenilmiştir. Üçüncü denek Özkan 9 yaş 4 aylık, ikinci sınıfın bahar döneminde öğrenme güçlüğü tanısı almış ve bir buçuk yıldır bir özel özel eğitim rehabilitasyon merkezinde özel eğitim destek hizmetlerinden yararlanmaktadır. Ön değerlendirmede 49 sözcük okuma akıcılığı ve üç doğru yanıt performansı göstermiştir. Özkan ile okuduğunu anlamaya yönelik çalışmalarda öğretmeninin soru cevap ve tekrarlı okuma yöntemlerini kullandığı öğrenilmiştir. Araştırmanın son katılımcısı Cem, 9 yaş 5 aylıktır. Üçüncü sınıfın başında öğrenme güçlüğü tanısı almış, bir yıldır bir özel özel eğitim rehabilitasyon merkezinde özel eğitim destek hizmetlerinden yararlanmaktadır. Ön değerlendirmede 47 sözcük okuma akıc1lığı ve 4 doğru yanıt performansı göstermiştir. Cem ile ağırlıklı olarak matematik işlemleri ve okuma hatalarına yönelik öğretimlerin yapıldığı öğretmeni tarafından bildirilmiştir.

\subsection{Bağımlı Değişken}

Çalışmanın bağımlı değişkenleri öğrencilerin metni anlama becerilerinin değerlendirildiği çoktan seçmeli test puanları ve metni anlatma becerilerinin değerlendirilmesinden elde ettikleri puanlardır.

İlk bağımlı değişken kapsamında öğrencilerin okuduğunu anlama performansları metinleri okuduktan sonra cevapladıkları çoktan seçmeli testler ile değerlendirilmiştir. Çalışmada araştırmacılar tarafından hazırlanmış 30 bilgi veren metin kullanılmıştır. Bu çalışmada bilgi veren metinler kullanılması, dördüncü sınıfa devam eden öğrencilerin, bu sınıf düzeyinde daha çok bilgi veren metinlerle karşılaşıyor olmaları ve akademik başarılarının bilgi veren metinleri anlamadaki başarıları ile yakından ilişkili olması nedeniyledir (Bastuğ, 2014). Metinlerin okunabilirlik düzeylerinin 4. sınıf öğrencileri için uygunluğu, Yeni Okunabilirlik Formülü (Bezirci ve Yılmaz, 2010) kullanılarak hesaplanmıştır. Okunabilirlik değerleri cümle başına düzen sözcük sayısı, sözcük hece ortalamaları ve metin içinde yer alan çok heceli sözcük oranı değerlendirilerek tespit edilmektedir. Tüm metinlerin uzunlukları 280-320 sözcük arasında değişmektedir. Her metin için hazırlanmış olan 10 soruluk çoktan seçmeli testler ile öğrencilerin metni anlama performansları değerlendirilmiştir. Testlerde doğru yanıtlar 1 puan, yanlış yanıtlar 0 puan olarak değerlendirilmektedir. Testler genel soru (metnin ne hakkında olduğu), hedef sözcük, olay sıralama, neden-sonuç, doğru-yanlış, özel bilgi sorusu (metinde geçen bilgi hatırlama), özetleme, 
başlık sorusu, çıkarım sorusu ve yazarın amacı olmak üzere farklı soru tiplerini içermektedir. Testlerde soru tipleri aynı sıra ile yer almaktadır. Tüm metinler ve testler araştırmacılar tarafından hazırlanmıştır ve uzman görüşleri alınarak pilot çalışmalar ile değerlendirilmiştir.

İkinci bağımlı değişken kapsamında öğrencilerden metni anlatmaları istenmiş ve anlatımları ses kaydına alınmıştır. Kayıtlar Özbek (2019) tarafından geliştirilen Metni Anlatma Puanlama Anahtarı (Ek-1) kullanılarak değerlendirilmiştir. Metni Anlatma Puanlama Anahtarı bilgi birim sayısı, doğruluk, cümle yapısı ve bilgi düzenleme olmak üzere dört maddeden oluşmaktadır. Her bir maddeden en düşük 1 en yüksek 4 puan alınabilmektedir. Puanlama anahtarından alınabilecek en düşük puan 4, en yüksek puan ise 16'dır.

\subsection{Bağımsız Değişken}

Çalışmanın bağımsız değişkeni KDSG yöntemine göre yürütülen 3D strateji öğretimidir. Öğrencilere okuma öncesi, okuma sırası ve okuma sonrasında kullanabilecekleri okuma stratejileri kazandırılarak okuduğunu anlama performanslarının geliştirilmesi hedeflenmiştir. Bağımsız değişkenin uygulaması işlem bölümünde anlatılmaktadır.

\section{5. İşlem}

Müdahale süreci öncelikle zayıf okuma başarısı gösteren ve öğrenme güçlüğü tanısı almış olan üç öğrenci ile bir pilot çalışma kapsamında uygulanmıştır. Pilot çalışmalardan elde edilen veriler ve gözlemler ışığında deney sürecinde düzenlemeler yapılmış ve araştırmanın veri toplama sürecine başlanmıştır. Veri toplama süreci diğer faktörlerin etkisinin en aza indirilmesi amaciyla 2019-2020 öğretim yılının başında, Eylül ve Ekim aylarında tamamlanmıştır. Bu amaçla her öğrenci ile haftada üç oturum olmak üzere dört haftada toplam 12 müdahale oturumu düzenlenmiştir. Uygulama aşaması her öğrenci için dört hafta sürmüştür. Müdahale oturumları ortalama 30-35 dakika sürmüştür. Uygulama güvenirliği ve gözlemciler arası güvenirlik değerlendirmeleri için oturumlarda ses kaydı yapılmıştır. İlk iki oturumda ön bilgilerin geliştirilmesi ve tartışma oturumlarına yer verilmiştir ve toplamda 10 müdahale oturumu verisi alınmıştır.

\subsubsection{Başlama Düzeyi Oturumları}

Başlama düzeyi değerlendirmelerine başlamadan önce öğrencilere çalışma ile ilgili açıklama yapılmıştır. Ardından öğrencilerden metinleri önce sesli sonra sessiz olmak üzere iki kez okumaları ve verilen testi yanıtlamaları istenmiştir. Son olarak öğrencilerden okudukları metinden neler öğrendiklerini anlatmaları istenmiştir. Tüm öğrenciler ile birer başlama düzeyi oturumu yapıldıktan sonra ilk öğrenci ile dört başlama düzeyi oturumu daha yapılarak müdahale aşamasına geçilmiştir. Ölçüt göz önünde bulundurularak diğer tüm öğrenciler ile başlama düzeyi değerlendirmelerine devam edilmiştir. Başlama düzeyi oturumları ortalama 15-20 dakika sürmüştür.

\subsubsection{Müdahale Oturumları}

Müdahale süreci KDSG (SRSD) öğretim yöntemine göre yürütülmüştür. KDSG öğretim yöntemi önceki bilgiyi geliştirme ve etkinleştirme, tartışma, model olma, ezberleme, destekleme ve bağımsız uygulama basamaklarından oluşmaktadır. Müdahale sürecine tüm öğrenciler ile okuduklarını daha iyi anlamak ve daha iyi hatırlayabilmek için neler yaptıkları sorularak başlanmıştır. Bu aşama KDSG yönteminin ilk basamağıdır ve bu aşamada öğrencilerin ön bilgilerinin geliştirilmesi hedeflenmektedir. Ardından tartışma basamağ 1 oturumunda bir metni okurken daha iyi anlamak için neler yaptığımız ve başka neler yapılabileceği üzerine konuşularak, öğrenilecek olan stratejiler ve hazırlanmış olan ipucu kartı öğrencilere tanıtılmıştır. Öğrencilere bu stratejiyi kullanmanın okuduklarını daha iyi anlamasına nasıl yardımcı olacağı açıklanmıştır. Önbilgileri geliştirme ve tartışma bölümlerinin amacı öğrenciyi çalışmaya hazırlamak ve strateji kullanımına ilişkin motivasyonunu arttırmaktır. Üçüncü basamak olan model olma aşaması ile metin okuma çalışmaları başlamıştır ve ilk model olma basamağı oturumundan itibaren müdahale 
aşaması verileri alınmaya başlanmıştır. Aşağıda bu aşamaların ayrıntılı açıklamalarına yer verilmiştir.

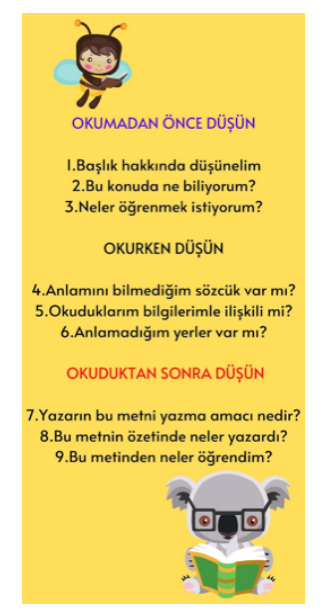

Şekil 1. Öğrencilere Verilen 3D İpucu Kart1

Model Olma: Bu aşamada uygulamacı bir masada öğrenci ile yan yana oturarak çalışmıştır. Strateji basamaklarını içeren ipucu kartı (Bkz., Şekil 1) masanın üzerinde bulundurulmuştur. Uygulamacı bu aşamada öğrenciye okuma öncesinde, okuma sirasında ve okuma sonrasında hedeflenen strateji basamaklarını uygulayarak model olmuştur. Bu sırada öğrencinin metninden farklı bir metni kullanmıștır. Araștırmacı yüksek sesle düşünerek ipucu kartında yer alan uygulama aşamalarına "Evet ipucu kartıma bakıyorum. Daha iyi anlamak için okumadan önce neler yapmalıyım? Başlık hakkında düşünelim! Başlığa bakayım "Bilgisayar Teknolojisi”... Yazar bilgisayarların nasıl kullanıldığını anlatmak istiyor bence. Kartıma bakayım, ben bu konu hakkında ne biliyorum? Ben bilgisayarların işimizi kolaylaştırdığını ve güzel oyunlar oynayabildiğimizi biliyorum..." gibi ifadeler kullanarak model olmuştur. Ardından öğrencinin de aynı şekilde kendi metnini aynı stratejileri kullanarak okumasını istemiş ve doğru tepkileri pekiştirmiştir.

Ezberleme: Her model olma oturumu sonunda ipucu kartı ile öğrencilerin pratik yapması ve strateji basamaklarını öğrenmeleri sağlanmıştır. Ayrıca öğrenciler ile Şekil 1'de yer alan ipucu kartının sadeleştirilmiş bir versiyonu hazırlanmıştır. Kart sadeleştirilirken stratejiler öğrenciye ipucu olacak şekilde kısaltılarak "Ne biliyorum, Ne ögrenmek istiyorum, Bilmediğim sözcük vb." şeklinde yazılmıştır. Model olma aşaması öğrenciler stratejinin basamaklarını yardımsız olarak sayabildiklerinde tamamlanmış ve destekleme aşamasına geçilmiştir.

Destekleme: Bu aşamada uygulamacı ipuçlarını geri çekerek ve öğrenciye verilen desteği azaltarak öğretime devam etmiştir. Yalnızca öğrencinin ihtiyacı olduğu durumlarda destek verilerek stratejileri kullanması sağlanmıştır. Destekleme oturumlarında öğrencilerin kendi hazırladıkları sadeleştirilmiş ipucu kartı kullanılmıştır. Uygulamacı gerekli durumlarda "Şimdi ne yapman gerekiyor?" gibi yönlendirici sorular sormuştur.

Bağımsız, Uygulamalar: Bu aşamada öğrencilere yalnızca metinler verilerek stratejileri kullanarak okumaları ve testi yanıtlamaları istenmiştir. Tüm denekler ile bağımsız uygulamalar tamamlanmıştır.

\subsection{3. İzleme Oturumları}

Müdahale oturumlarının ardından 7., 14. ve 21. günde izleme verileri alınmıştır. Bu değerlendirmeler başlama düzeyi ile aynı şekilde yapılmıştır. Öğrencilerden metni dikkatlice bir kez sesli bir kez sessiz okuyarak testi yanıtlamaları ve ardından metni anlatmaları istenmiştir. Uygulamacı öğrencilere herhangi bir ipucu vermemiş ve yardımda bulunmamıştır. 


\subsection{Uygulamacı ve Ortam}

Tüm değerlendirme ve müdahale oturumları katılımcıların destek eğitim aldıkları özel eğitim merkezlerinde özel eğitim alanında doktora derecesine sahip olan ikinci araştırmacı tarafından gerçekleştirilmiştir. Oturumlar sırasında öğrencilerin dikkatini dağıtabilecek uyaranlar ortamdan kaldırılmıştır. Öğrencilerin rahat çalışabileceği bir masa ve sandalyede, uygulamacı ile yan yana oturarak çalışmalar tamamlanmıştır. Çalışmalar özel eğitim rehabilitasyon merkezlerinin bireysel eğitim sınıflarında gerçekleştirilmiştir. Tüm öğrenciler ile aynı materyaller ve destekler kullanılmıştır.

\subsection{Uygulama Güvenirliği ve Gözlemciler Arası Güvenirlik}

Oturumlarda alınan ses kayıtlarının \%30’u dinlenerek çalışmanın uygulama güvenirliği değerlendirilmiştir. Araştırmanın başlama düzeyi, müdahale ve izleme aşaması oturumlarından her katılımcı için seçkisiz olarak belirlenen ses kayıtları iki bağımsız gözlemci tarafından dinlenerek uygulama güvenirliği için oluşturulmuş kontrol listesi ile değerlendirilmiştir. Yapılan değerlendirmeler sonucunda araştırmanın uygulama güvenirliğinin \%98 olduğu belirlenmiştir. Uygulama güvenirliğinin belirlenmesinde araştırmacı ve gözlemci arasındaki görüş birliği sayısı, görüş birliği ve görüş ayrılı̆̆ 1 sayılarının toplamına bölünüp 100'le çarpılarak hesaplama yapılmıştır (House, House ve Campbell, 1981). Öğrencilerin metni anlatma değerlendirmeleri kayıtları ve çoktan seçmeli testleri başlama düzeyi, müdahale ve izleme aşaması bilgisi olmaksızın seçkisiz bir şekilde seçilerek iki bağımsız gözlemci ile paylaşılmıştır. Öğrencilerin metni anlama testlerine verdikleri cevaplar kontrol edilmiş ve gözlemciler tarafindan rubrik ile kayıtlar puanlanmıştır. Araştırmacının puanlamaları ve bağımsız gözlemcilerin değerlendirmeleri SPSS programına aktarılarak Kendall's Tau-b uyuşum katsayısı hesaplaması yapılmıştır. Gözlemciler arası güvenirlik okuduğunu anlama testleri için \%100 metni anlatma puanları için \%92 olarak belirlenmiştir.

\section{BULGULAR}

Katılımcıların okudukları metinlere ilişkin yanıtları test soruları ve metne ilişkin anlatımları değerlendirilmiştir. Bu iki değişken temelinde tüm katılımcıların başlama düzeyi, müdahale ve izleme oturumlarından elde ettikleri betimsel istatistikler Tablo 1'de verilmiştir. $\mathrm{Bu}$ oturumlara ilişkin veriler ise Grafik 1 ve Grafik 2'de sunulmuştur. Grafikler görsel analiz yapılarak incelenmiştir. Metni anlama testlerinden alınabilecek en düşük puan 0 en yüksek puan ise 10'dur. Metni anlatma değerlendirmelerinden ise en düşük 4, en yüksek 16 puan alınabilmektedir.

Tablo 1. Katılımcıların Başlama Düzeyi, Müdahale ve İzleme Oturumlarındaki Performanslarının Betimsel İstatistikleri

\begin{tabular}{|c|c|c|c|c|c|c|c|c|}
\hline \multirow[b]{2}{*}{ Öğrenci } & \multirow[b]{2}{*}{ Aşama } & \multirow[b]{2}{*}{$\begin{array}{c}\text { Oturu } \\
\mathrm{m} \\
\text { Sayis1 }\end{array}$} & \multicolumn{3}{|c|}{ Metni Anlama Testi Puanı } & \multicolumn{3}{|c|}{ Metni Anlatma Puanı } \\
\hline & & & $\mathrm{X}$ & ss & Ranj & $X$ & ss & Ranj \\
\hline \multirow{3}{*}{ Mazhar } & Başlama Düzeyi & 5 & 2.6 & .54 & $2-3$ & 4.4 & .54 & $4-5$ \\
\hline & Müdahale & 10 & 7.4 & .84 & $6-9$ & 10.3 & 1.7 & $7-13$ \\
\hline & İzleme & 3 & 7.3 & .57 & $7-8$ & 9 & 1 & $8-10$ \\
\hline \multirow{4}{*}{ Fuat } & Başlama Düzeyi & 6 & 2.4 & .54 & $2-3$ & 4.2 & .44 & $4-5$ \\
\hline & Müdahale & 10 & 7.1 & .73 & $6-8$ & 8.3 & 1.33 & $6-10$ \\
\hline & İzleme & 3 & 6.3 & .57 & $6-7$ & 7.3 & .57 & $7-8$ \\
\hline & Başlama Düzeyi & 7 & 2.6 & 1 & $1-4$ & 4.1 & .40 & $4-5$ \\
\hline \multirow[t]{2}{*}{ Özkan } & Müdahale & 10 & 6.8 & .78 & $6-8$ & 8.1 & 1.1 & $7-10$ \\
\hline & İzleme & 3 & 6.3 & .57 & $6-7$ & 6.3 & .57 & $6-7$ \\
\hline $\mathrm{Cem}$ & Başlama Düzeyi & 8 & 2.8 & .64 & $2-3$ & 4.1 & .35 & $4-5$ \\
\hline
\end{tabular}




\begin{tabular}{lccccccc}
\hline Müdahale & 10 & 6.8 & .78 & $6-8$ & 9.5 & 1.08 & $8-11$ \\
İzleme & 3 & 6.6 & .57 & $6-7$ & 7.6 & .57 & $7-8$ \\
\hline
\end{tabular}

Tablo 1 incelendiğinde müdahale oturumlarında katılımcıların metni anlama testi ve metni anlatma puanları ortalamalarının artış gösterdiği görülmektedir. İzleme oturumlarında ise tüm katılımciların metni anlama testi ve metni anlatma puanlarının müdahale oturumlarına göre ufak bir düşüş gösterdiği ancak başlama düzeyinin üzerinde oldukları görülmektedir.

Araştırmanın ilk katılımcısı olan Mazhar'ın başlama düzeyinde gerçekleştirilen 5 değerlendirmede metni anlama testi ortalaması 2.6 , metni anlatma puan ortalaması ise 4.4'tür. 3D strateji öğretimi müdahale oturumlarına geçildiğinde Mazhar'ın metni anlama testi ortalaması 7.4 olurken, metni anlatma puanı ortalaması 10.3 olmuştur. Son müdahale oturumunu takip eden 714-21 gün sonra yapılan izleme oturumu değerlendirmelerinde metni anlama testi ortalaması 7.3 ve metni anlatma puanı ortalaması 9 olmuştur.

Araştırmanın ikinci katılımcısı olan Fuat'ın başlama düzeyinde gerçekleştirilen 6 değerlendirmede metni anlama testinde ortalama 2.4, metni anlatmada ise ortalama 4.2 puan elde etmiştir. 3D strateji öğretimi müdahale oturumlarında metni anlama testi ortalaması 7.1 , metni anlatma puanı ortalaması 8.3 olmuştur. Son müdahale oturumunu takip eden 7-14-21 gün sonra yapılan izleme oturumu değerlendirmelerinde ise 6.3 metni anlama testi ortalamasına ve 7.3 metni anlatma puanı ortalamasına sahip olduğu görülmektedir.

Araştırmanın üçüncü katılımcısı olan Özkan'ın başlama düzeyinde gerçekleştirilen 7 değerlendirmede metni anlama testi ortalamas 2.6 , metni anlatma puanı ortalaması 4.1'dir. 3D strateji öğretimi müdahale oturumlarında Özkan'ın metni anlama testi ortalaması 6.8, metni anlatma ortalaması 8.1 'dir. Son müdahale oturumunu takip eden 7-14-21 gün sonra yapılan izleme oturumu değerlendirmelerinde ise hem metni anlama testinde hem de metni anlatma puanında ortalama 6.3 düzeyinde bir performans göstermiştir.

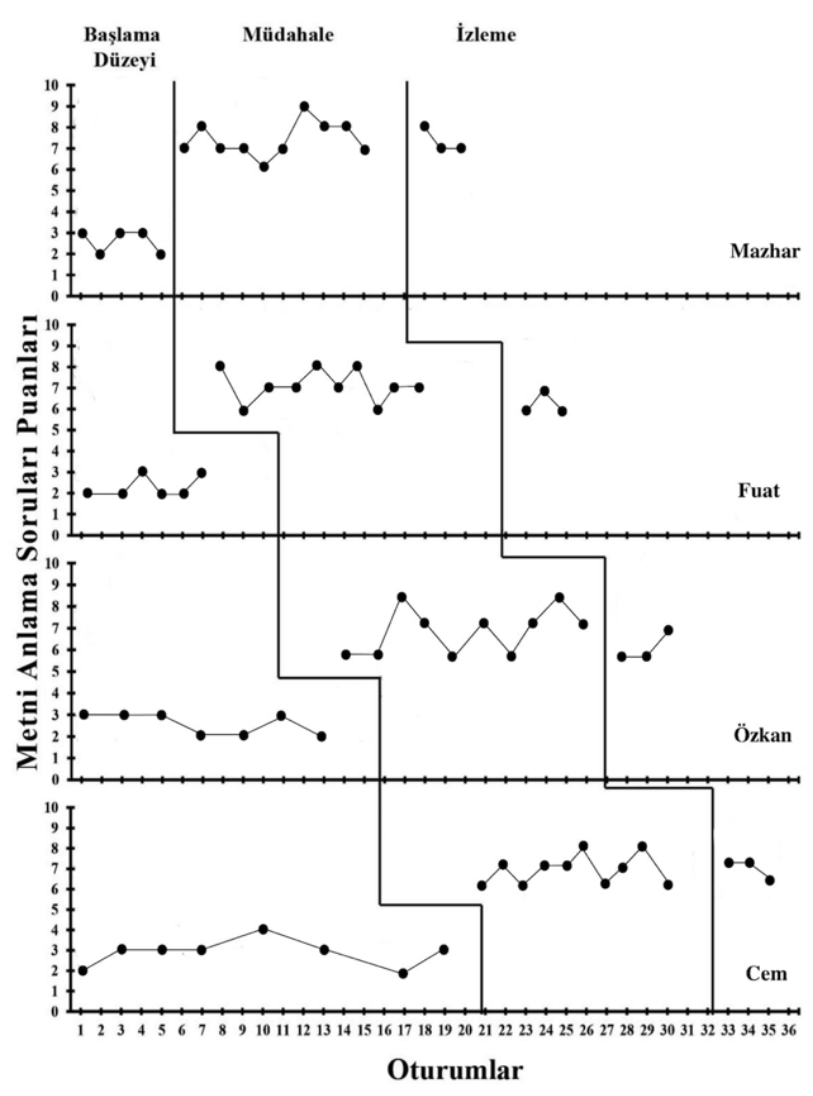

Grafik 1. Katılımcıların Metni Anlama Soruları Puanları 
Dördüncü ve son katılımcı olan Cem'in başlama düzeyinde gerçekleştirilen 8 değerlendirmede metni anlama testinde ortalama 2.8 , metni anlatmada ise ortalama 4.1 puan elde etmiştir. 3D strateji öğretimi müdahale oturumlarında metni anlama testi ortalaması 6.8 olurken, metni anlatma puanı ortalaması ise 9.5 olmuştur. Son müdahale oturumunu takip eden 7-14-21 gün sonra yapılan izleme oturumu değerlendirmelerinde Cem metni anlama testinde ortalama 6.6 ve metni anlatma puanı değerlendirmesinde ortalama 7.6 düzeyinde performans göstermiştir. Katılımcıların metni anlama testi puanları Grafik 1'de sunulmuştur.

Görsel analiz yapıldığında tüm katılımcılar için metni anlama testi puanları bağımlı değișkeni açısından örtüșmeyen veri yüzdesi $\% 100$ olarak hesaplanmıștır. Örtüşmeyen veri yüzdesi bir katılımcının başlama düzeyinde elde ettiği en yüksek puanın üzerinde kalan müdahale verilerinin yüzdesidir (Kratochwill ve diğ., 2010). Ayrıca tüm katılımcıların ilk üç müdahale oturumu puanları incelendiğinde, bağımsız değişkenin metni anlama testi puanları üzerindeki doğrudan etkisi, oluşan acil etki (immediacy effect) ile görülmektedir. Acil etki başlama düzeyinin son üç oturumu ile müdahale aşamasının ilk üç oturumu arasında oluşan farkın oluşum şeklidir. Başka bir deyişle, müdahale başladıktan sonra tüm katılımcıların puanlarında başlama düzeyi puanlarına göre aşamalı bir şekilde değil, hızlı bir artış göstermiştir. Katılımcıların izleme oturumları verileri başlama düzeyi verileri ile karşılaştırıldığında hafif bir düşüşle kazanımlarını korudukları görülmektedir. Metni anlatma puanlarına ilişkin oturumlardan elde edilen veriler Grafik 2'de sunulmuştur.

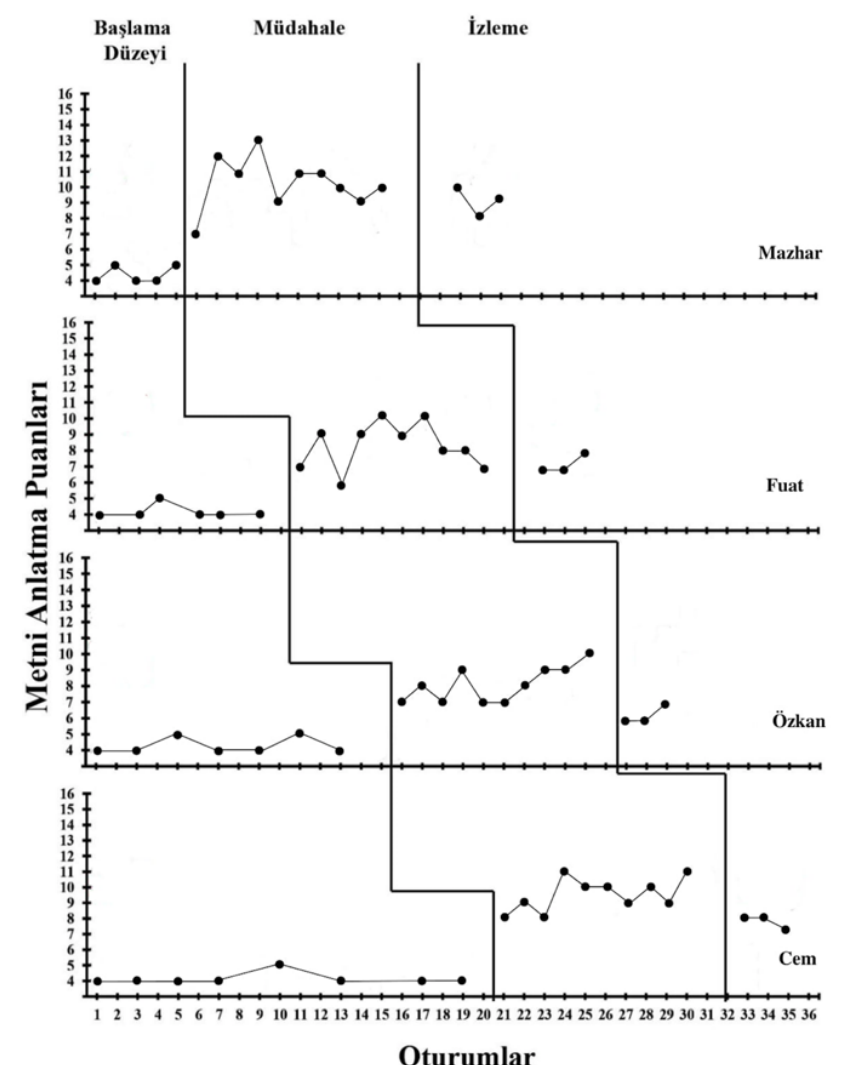

\section{Grafik 2. Katılımcıların Metni Anlatma Puanları}

Görsel analiz yapıldığında tüm katılımcılar için metni anlatma puanları bağımlı değişkeni açısından örtüşmeyen veri yüzdesi \%100 olarak hesaplanmıștır. Ayrıca tüm katılımcıların ilk üç müdahale oturumu puanları incelendiğinde, bağımsız değișkenin metni anlama testi puanları üzerindeki doğrudan etkisi, oluşan acil etki ile görülmektedir. Katılımcıların izleme oturumları 
verileri başlama düzeyi verileri ile karşılaştırıldığında hafif bir düşüşle kazanımlarını korudukları görülmektedir.

\section{TARTIŞMA VE SONUÇ}

Bu araştırmada KDSG modeline göre yürütülen 3D strateji öğretimi ile öğrenme güçlüğü olan dört öğrencinin okuduğunu anlama becerilerinin geliştirilmesi amaçlanmıştır. Bu kapsamda öğrencilerin metni anlama sorularını yanıtlama ve metni anlatma becerileri değerlendirilmiştir. Müdahale oturumlarında dört öğrencinin de okuduğunu anlama performansları artış göstermiş ve müdahale oturumlarındaki ortalamaları başlama düzeyinin yaklaşık iki katından fazla olmuştur. İzleme oturumlarında ise tüm katılımcılar için bu artışın önemli ölçüde korunduğu dikkati çekmiştir. İzleme oturumlarında öğrencilerin okuduğunu anlama performansları bir miktar düşüş gösterse de tüm katılımcılar başlama düzeylerinin oldukça üstünde performans göstermişlerdir. KDSG öğretim modeline göre yapılan 3D strateji öğretiminin farklı yaş düzeylerindeki öğrencilerin okuduğunu anlama ve akademik becerilerine olan katkısı birçok çalışmada gösterilmiş bir bulgudur (Graham, 2006; Johnson ve diğ., 1997; Johnson, Reid ve Mason, 2011; Mason, 2004; Mason, 2013). Bu bağlamada, bu araştırmadan elde edilen sonuçlar alanyazınla uyumludur.

$\mathrm{Bu}$ çalışmanın sonucunda KDSG modeline göre uygulanan 3D stratejisinin öğrencilerin okuduğu anlama performanslarının arttırılmasında etkili olduğu görülmektedir. Öğrenme güçlüğü çocuklarla yapılan uygulamalar ve araştırmalarda bu çocukların strateji kullanmakta yetersiz oldukları ifade edilse de bunda strateji öğretimiyle karşılaşmamalarının ve bu konuda kendilerini geliştirecek firsatlara sahip olmamalarının da rolü olduğu düşünülmektedir. Dolayısıyla strateji öğretimini temel alan tüm çalışmalarda böyle etkili sonuçlar görülmektedir (Mason, 2004; Mason, Hickey Snyder, Jones ve Kedem, 2016). Öğrenme güçlüğü olan öğrenciler akranları ile karşılaştırıldıklarında karşılaştıkları güçlüklerde stratejiler geliştiremede ya da var olan stratejilerini uygun bir şekilde kullanmada daha zayıf performanslar göstermektedirler (Fırat ve Koçak, 2019). Müfredatta okuduğunu anlama stratejilerine yönelik hedefler bulunmaktadır ancak öğrenme güçlüğü olan öğrencilerin stratejilerin kullanımına adım adım açık bir şekilde model olunan ve tekrarlı uygulamalara ihtiyaçları vardır. Bu bağlamda elde edilen sonuçlarda KDSG modelinin ve 3D stratejisinin etkililiğinin yanı sıra uygulamacının öğrenme güçlüğü olan öğrencilerle yaptığı birebir çalışmaların büyük bir katkısının olduğu düşünülmektedir. Öğrenme güçlüğü olan öğrenciler sınıfta yapılan öğretimler esnasında çoğu zaman öğretmenin verdiği yönergeleri takip edememekte ya da ipuçlarını kullanamamakta ve birçok beceride ustalaşmak için yeterli zamana sahip olamamaktadırlar (Rogevich ve Perin, 2008; Wong, 2011). Bunun yanı sıra, öğrenme güçlüğü olan çocuklar dikkat, çalışma belleği gibi sınırlılıkları nedeni ile gereksinimlerine göre uyarlanmamış öğretimlerde yeteri kadar faydalanamamaktadır. Bu nedenle, bu öğrencilerle yürütülen daha sık tekrar ve model olmanın yer aldığ 1 birebir müdahalelerin hedef becerileri geliştirmelerinde daha etkili olduğu belirtilmektedir. Nitekim Hedin, Mason ve Gaffney (2011) öğrenme güçlüğü olan üç öğrenci ile yaptıkları çalışmada 3D stratejisini kullanarak okuduğunu anlama becerilerini arttırmalarında öğrencilerin öğretmenle bire bir aldıkları eğitimlerin etkili olduğunu ifade etmişlerdir. Rogevich ve Perin'in (2008) de belirttiği gibi öğretmenlerin bilişsel stratejileri kullanmaya model olmaları ve Almasi tarafindan ifade edildiği gibi öğretmenlerin öğrencilerine stratejileri ne zaman ve nasıl kullanmaları gerektiği konusunda bilgi vermeleri öğretimin etkililiğini artıran faktörlerdir. (Almasi, 2003). Dolayısıyla, bu çalışmada 3D strateji öğretiminin bireysel uygulanması, sık tekrarlara yer verilmesi öğretimin model olma ve bilgilendirme gibi aşamaları içermiş olması uygulanan strateji öğretiminin etkililiğini sağlayan diğer faktörler olarak değerlendirilmektedir.

Oturumların yürütülmesi esnasında elde edilen nitel gözlemlerin de araştırmanın sonuçlarının yorumlanması açısından önemli olduğu düşünülmektedir. Bu gözlemlerden ilki, katılımcıların ipucu kartından yararlandıkları model olma ve destekleme aşamasında stratejileri 
iyi bir şekilde kullandıklarına ilişkindir. Buna karşın, katılımcılar bağımsız uygulamalar aşamasına geçiş yaparken oldukça zorlanmışlardır. Bağımsız uygulamalar aşamasında ise üç katılımcı tekrar uygulamacının yönlendirmesine ihtiyaç duymuştur. $\mathrm{Bu}$ durum uygulamacı modeli ile çalışılan araştırmalarda sıklıkla karşılaşılan bir durumdur (Hedin, Mason ve Gaffney 2011; Kucan ve Beck, 2003). Ek olarak öğrenme güçlüğü olan öğrencilerin bir beceri üzerinde performans sergilerken bağımsızlaşmakta güçlük yaşadıkları ve daha çok dışa bağımlı oldukları bilinmektedir (Bender, 2012). Buna karşın, katılımcıların bağımsız uygulamalarda stratejileri bağımsız yürütmek için çaba harcadıkları ve zaman zaman yardıma ihtiyaç duysalar da strateji kullanımını sürdürebildikleri görülmüştür. Dolayısıyla öğrencilere bu firsatın verilmesi daha sonraki çalışmaları için önemli bir adımdır.

İkinci olarak, katılımcıların metne ilişkin soruları yanıtlama ve metni anlatma performansları birlikte değerlendirildiğinde metni anlatma becerisinde daha çok zorlandıkları görülmüştür. Özellikle izleme oturumlarında öğrencilerin metni anlatma performanslarında ciddi bir düşüş gözlenmiştir. Bu durumun metni anlatma görevinin daha karmaşık bir bilişsel süreç gerektirmesi ile ilişkili olduğu düşünülmektedir. Metni anlatmada öğrencilerin metindeki bilgileri hatırlamaları, bu bilgileri organize etmeleri ve dilin kurallarına uygun bir şekilde ifade etmeleri gerekmektedir. Oysa öğrenme güçlüğü olan öğrencilerin bilgiyi hatırlama ve organize etmede etkili çalışma belleği becerilerinde sınırlılıklar yaşadıkları, ifade edici dilde ve sözcük bilgisinde de yetersiz oldukları bilinmektedir (Berkeley, Scruggs ve Mastropieri, 2010). Bu durum onların metni anlamlandırmalarını ve yapılandırmalarını zorlaştırmaktadır (Cain ve Oakhill, 2011). Dolayısıyla metni anlatmalarını istemek öğrenme güçlüğü olan öğrencilerin pek çoğu için daha zor bir görev olabilmektedir (Winograd, 1983). Çoktan seçmeli testlerde ise soru kökü ve ş1klar öğrenciler için ipucu sağlayarak metne ilişkin bilgileri hatırlamalarını kolaylaştırmaktadır (Applegate, Applegate ve Modla, 2009). Buna karşın, uygulamalarda öğrenciler bu görevlerde zorlansa da hepsi başlama düzeyine göre oldukça yüksek performans göstermişlerdir.

Tek denekli deneysel desen araştırmalarında bulgular incelenirken görsel analiz ile düzey, eğim, değişkenlik, acil etki, örtüşme ve benzer aşamalardaki tutarlılık gibi altı farklı boyut incelenir (Fisher, Kelley ve Lomas, 2003). Öğrencilerin her iki bağımlı değişkende düzeylerinin bağımsız değişkenin uygulanması ile yükselme gösterdiği ve bu yükselmenin ilk müdahale oturumundan itibaren kendini gösterdiği görülmektedir. Bu çalışmada tüm katılımcılar için her iki bağımlı değişkende örtüşmeyen veri yüzdesi \%100 olarak hesaplanmıştır. Bu durum tüm öğrenciler için müdahale ve izleme oturumu puanlarının en yüksek başlama düzeyi performanslarından dahi daha fazla olduğu anlamına gelmektedir. Ayrıca öğrencilerin her iki bağımlı değişkende gösterdikleri performans grafiklerinin örtüştüğü ve araştırmada ölçümlerin öğrencilerin oturumlarda gösterdikleri performansı belirlemede tutarlı sonuçlar verdiği anlaşılmaktadır. Son olarak, grafikler ve Tablo 1'de yer verilen ranjlar incelendiğinde başlama düzeyi, müdahale ve izleme aşamalarında katılımcıların bağımlı değişken düzeyleri değişkenliği çok yüksek değildir ve başlama düzeyi verilerinin tutarlılık gösterdiği görülmektedir. $\mathrm{Bu}$ bağlamda, 3D strateji öğretiminin bağımlı değişkenler üzerinde önemli bir etkisinin olduğu ve elde edilen bulguların tek denekli araştırmalar için belirlenen bağımsız değişken etki belirleme ölçütlerini sağladığı görülmektedir (Kratochwill ve diğ., 2010).

Her iki bağımlı değişkene ait veriler incelendiğinde 3D strateji öğretimi müdahalesinden katılımcılar farklı düzeylerde yarar sağladıkları ifade edilebilir. Müdahale oturumlarının sonucunda ise tüm öğrencilerin performansında ilerleme görülmekle birlikte müdahalenin Mazhar ve Fuat'ın performansı üzerinde diğer katılımcılardan daha etkili olduğu görülmektedir. Öğrencilerin metni anlatma performansları incelendiğinde ise başlama düzeyindeki performans ranjlarının aynı olduğu görülmektedir. Müdahale oturumlarının sonunda ise Mazhar ve Cem'in ortalamalarındaki artışın diğer öğrencilerin ortalama artışından daha yüksek olduğu görülmektedir. Öğrencilerin çoktan seçmeli test ve metni anlatma değerlendirmelerinden aldıkları puanları izleme oturumlarında hafif bir düşüşle korudukları görülmektedir. Metni anlatma becerilerinde ise tüm katılımcılar çoktan seçmeli teste göre daha fazla bir performans düşüşü 
yaşamışlardır. Strateji öğretiminin zayıf akademik başarı gösteren öğrencileri desteklemekte etkili olduğu bilinse de (Mason, 2004) bu etkililiğin öğrencilerin bilişsel yeterlilikleri ölçüsünde olduğu da belirtilmektedir (Baker, Gertsen, ve Scanlon, 2002; Pressley ve Hilden, 2005). Başka bir deyişle her öğrenci kendi yeterlilikleri temelinde müdahaleden farklı oranda yararlanmaktadır. Öğrencilerin dikkat ve çalışma belleği gibi özellikleri okuma sırasında strateji kullanımlarını ve okuma esnasında amaçlanan anlama düzeyini etkilemektedir (Van den Broek, Lorch, Linderholm ve Gustafson, 2001). Bunun yanı sıra öğrenme güçlügü olan öğrencilerin motivasyon yetersizliklerinin anlama becerileri üzerinde oldukça etkili olduğu da bilinmektedir (Gottfried, 1990; Schultz ve Switzky, 1993). Çalışmada öğrencilerin okunan bilgi veren metnin konusuna göre değişen motivasyonları olduğu araştırmacının dikkatini çekmiştir. Öğrencilerin ilgi çekici buldukları metinlerin çalışıldığı oturumlarda daha yüksek metni anlatma performansı gösterdikleri görülmüştür. $\mathrm{Bu}$ durum öğrencilerin müdahaleden farklı düzeylerde faydalanmalarının sebeplerinden bir tanesi olabilir. Nitekim nicel olarak değerlendirmeler yapılmasa da uygulamalar esnasında öğrencilerin dikkat, dil ve çalışmaya ilişkin motivasyonlarının farklılıklar gösterdiği gözlenmiştir. Örneğin, çalışmada okuduğunu anlama performansı önemli gelişme gösteren Mazhar ipucu kartını kısaltarak hazırlanması aşamasında oldukça ilgili olmuş ve uygulamacıya fikirler önermiş, kartını süsleyerek hazırlamak istemiștir. Öte yandan diğer katılımcılara kıyasla daha düşük gelişme gösteren Özkan deney sürecinde uygulamacının yönergelerine en çok ihtiyaç duyan öğrenci olmuştur ve kart hazırlama sürecinde yalnızca uygulamacının söylediklerini yapmıştır. Gelecek araştırmalarda bu değişkenlerin müdahaleler sonucunda elde edilen sonuçlara ve öğrencilerin performansına olan etkilerinin incelenmesi gerektiği açıktır.

Çalışmaya katılan öğrencilerin çoktan seçmeli testlerde en çok zorlandıkları soruların hedef sözcük ve çıkarım soruları olduğu görülmüştür. Metin içerisinde tanımı yapılarak tanıtılan konuya ilişkin potansiyel yeni sözcükler testlerde soru olarak yer almış ve anlamları sorulmuştur. Öğrencilerin tutarlı bir şekilde bu sorulara yanlış yanıt verdikleri görülmüştür. Benzer şekilde çıkarım sorularında öğrencilere metinden anlaşılabilen ancak birebir metinde yer almayan bilgiler sorulmuştur. Tüm katılımcıların çıkarım sorularında da başlama düzeyi, müdahale ve izleme oturumlarında diğer soru tipleri ile karşılaştırıldığında daha çok sayıda yanlış yanıtlar verdikleri görülmektedir. Bu durum çıkarım yapmanın da ayrı bir beceri olarak ele alınması gerektiğini düşündürmüştür.

Son olarak bu çalışmanın sonuçları yorumlanırken öğrencilerin daha önce strateji öğretimine ilişkin bir tecrübelerinin olmayışı ve bu tip uygulamaların onlar için yeni olduğu göz önünde bulundurulmalıdır. Alanyazında strateji öğretimi ile ilgili yapılan çalışmalar yoğun olmasına rağmen okullarda strateji öğretimi yaygın değildir (Ateş ve Yıldırım, 2014). Bunun nedenlerinden biri öğretmenlerin stratejileri uygulamada zorlanmaları ve bu stratejilere ilişkin programlarının karışıklığından dolayı zorluk çekmeleridir (Scharlach, 2008). Nitekim son yıllarda yapılan araştırmalar öğretmenlerin bu stratejileri uygularken zorlandıklarını, öğretmenlerin stratejiler ile ilgili yeterli bilgiye sahip olmadıklarını göstermektedir (Block ve Pressley, 2007). $\mathrm{Bu}$ sonuçlar stratejilerin öğretmenlerin uygulayabilmesi için anlaşılır bir şekilde hazırlanması gerekliliğini ortaya koymaktadır (Scharlach, 2008). Ayrıca öğretmenler, öğrencilerin sadece okuyarak nasıl anladıklarını öğrenebileceklerine inanmaktadırlar (Block ve Pressley, 2007).

Elde edilen sonuçlar bağlamında öğrenciler ile yapılan uygulamalara yönelik öneriler verilebilir. İlk olarak öğretmenlere bu konunun önemi ve uygulanması konusunda eğitimler verilmesi gerekmektedir. Öğretmenler sınıflarda bu uygulamalara daha fazla yer verdiklerinde öğrenme güçlüğü olan öğrencilerin okuduğunu anlama becerilerinde görülen olumlu değişimler daha uzun süreli olacaktır ve öğrencilerin edindikleri stratejileri farklı öğrenme alanlarına genelleyebilmeleri mümkün olacaktır. Öğrenciler stratejileri kullanmayı öğrendiklerinde bir sorunla karşılaştıklarında nasıl bir çözüm yolu izleyeceklerine ilişkin deneyimler kazanırlar. Bu deneyimler matematik ve fen bilgisi gibi diğer akademik alanlarda öğrenilecek yeni stratejilerin kazanılmasını kolaylaştıracaktır. Bir diğer önemli nokta ise ipucu kartlarının kullanılmasıdır. 
İpucu kartının katılımcılar tarafından aktif olarak kullanılması sınıflarda ihtiyacı olan öğrenciler için bu tür desteklerin kullanışlı olacağını göstermektedir. Uygulama adımları açık olarak verildiğinde öğrenciler stratejileri kullanarak daha yüksek başarı gösterebilmektedir. Zamanla destekler geri çekilerek öğrencilerin bağımsızlaşması sağlanmalı ve öğrencilerin stratejileri içselleştirmeleri için kendi sözcükleri ile yeni biçimlerde kartlar hazırlamaları teşvik edilmelidir.

$\mathrm{Bu}$ çalışmadan elde edilen sonuçlar ileri araştırmalar ve uygulamalar için bazı öneriler sunmaktadır. Bunlardan ilki, katılımcı sayısına iliş̧indir. Bu çalışmanın sonuçları deseni itibariyle dört katılımcıya ilişkin elde edilen bulgular çerçevesinde yorumlanmıştır. Gelecek araştırmalarda farklı özellikler gösteren öğrencilerle ve farklı sayıdaki öğrenci grupları ile çalışabileceği düşünülmektedir. Bu kapsamda, büyük gruplar ile yapılacak olan KDSG modeline göre yürütülen 3D strateji öğretiminin etkisini belirleyen çalışmalar yapılması ve sınıf içerisinde küçük grup etkinlikleri ile etkililiğin belirlenmesi gelecek araştırmalarda çalışılabilecek konular arasındadır. İkinci olarak, tam deneysel çalışmalar ile 3D strateji öğretiminin farklı okuduğunu anlama müdahaleleri ile etkililik açısından karşılaştırılabilir.

Sonuç olarak, okulun ilk yıllarında okuduğunu anlamada yetersiz performans sergileyen pek çok öğrenci ilerleyen y1llarda da akademik problemler geliştirmektedir (Scarborough, 1998). $\mathrm{Bu}$ nedenle öğrencilerin okuduğunu anlama problemlerinin erken belirlenmesi ve müdahale edilmesi ilerleyen yıllarda yaşanacak problemleri önlemede ya da azaltmada etkili olacaktır (Elbro ve Petersen, 2004; Partanen ve Siegel, 2014; Simmons ve diğ., 2008). Bu bağlamda bu çalışma öğrenme güçlüğü olan öğrencilerin yaşadıkları okuduğunu anlama problemlerinin erken müdahalesine ilişkin alana önemli bulgular sunmaktadır.

\section{KAYNAKÇA}

Aktaş, N. (2015). Okuma öncesi strateji öğretiminin 4. sinıf ögrencilerinin ekrandan okuduğunu anlama düzeyine etkisi. (Yayımlanmamış Yüksek Lisans Tezi). Gazi Üniversitesi Eğitim Bilimleri Enstitüsü. Ankara.

Alberto, P. A. ve Troutman, A. C. (2009). Applied behavior analysis for teachers (8th ed.). Upper Saddle River, NJ: Merrill Prentice Hall.

Almasi, J. (2003). Teaching strategic processes in reading. New York: Guilford.

Applegate, M. D., Applegate, A. J. ve Modla, V. B. (2009). "She's my best reader; she just can't comprehend": Studying the relationship between fluency and comprehension. The Reading Teacher, 62(6), 512-521.

Ateş, S. ve Yıldırım, K. (2014). Sınıf öğretmenlerinin okuma becerisine yönelik uygulamaları: Strateji Öğretimi ve Anlama. Elementary Education Online, 13(1), 235-257.

Atik-Çatak, A. ve Tekinarslan, E. (2006). Powerpoint sunu programıla hazırlanan okuma materyalinin eğitilebilir zihin engelli öğrencilerin okuduğunu anlama becerisi üzerine etkisi. Abant İzzet Baysal Üniversitesi Ë̆itim Fakültesi Dergisi, 8(2), 107-124.

Baker, S., Gertsen, R. ve Scanlon, D. (2002). Procedural facilitators and cognitive strategies: Tools for unraveling the mysteries of comprehension and the writing process, and for providing meaningful access to the general curriculum. Learning Disabilities Research and Practice, 17, 65-77.

Bastug, M. (2014). The structural relationship of reading attitude, reading comprehension and academic achievement. International Journal of Social Sciences and Education, 4(4), 931946.

Bender, W. N. (2002). Differentiating instruction for students with learning disabilities. Thousand Oaks, Ca: Corwin Press. 
Bender, W. (2012). Öğrenme güçlü̆̆̈̈ olan bireyler ve eğitimleri- özellikleri, tanılama ve ögretim stratejileri Çeviri Editörü Hakan Sarı, Ankara: Nobel Yayınevi.

Berkeley, S., Scruggs, T. E. ve Mastropieri, M. A. (2010). Reading comprehension instruction for students with learning disabilities,1995-2006: A meta analysis. Remedial and Special Education, 31(6), 423-436.

Bezirci, B. ve Yılmaz, A. E. (2010). Metinlerin okunabilirliğinin ölçülmesi üzerine bir yazılım kütüphanesi ve Türkçe için yeni bir okunabilirlik ölçütü. DEÜ Mühendislik Fakültesi Fen Bilimleri Dergisi, 12(3), 49-62.

Bilgi, A. D. ve Özmen, E. R. (2014). Uyarlanmış çok ögeli bilişsel strateji öğretiminin zihinsel engelli öğrencilerin metin anlama sürecinde kullanılan üstbilişsel strateji bilgisini kazanmalarında etkisi. Kuram ve Uygulamada Ë̆itim Bilimleri, 14(2), 693-714.

Block, C. C. ve Pressley, M. (2007). Best practices in teaching comprehension. In L. B. Gambrell, L. M. Morrow, \& M. Pressley (Eds.). Best practices in literacy instruction (3rd ed., pp. 220-242). New York: Guilford.

Cain, K. ve Oakhill, J. (2011). Matthew Effects in young readers: reading comprehension and reading experience aid vocabulary development. Journal of Learning Disabilities, 44(5), 431-443.

Cora-İnce, N. (2007). Zihin engelli çocuklara okuduğunu anlama becerilerinin ögretilmesinde işbirlikçi ögrenme yaklaşımı ile sunulan öğretim programının etkililiğinin incelenmesi. (Yayınlanmamış Doktora Tezi). Ankara Üniversitesi Eğitim Bilimleri Enstitüsü. Ankara.

Coşkun, S. (2011). Bilişsel farkındalık stratejilerine dayalı okuma eğitimi etkinliklerinin okuduğunu anlama becerilerini geliştirmeye etkisi. (Yayımlanmamış Yüksek Lisans Tezi). Abant İzzet Baysal Üniversitesi. Bolu.

Dabarera, C., Renandya, W. A. ve Zhang, L. J. (2014). The impact of metacognitive scaffolding and monitoring on reading comprehension. System, 42, 462-473.

Deniz, S. ve Aslan, Y. (2020). Özel öğrenme güçlüğü olan bir öğrencide hikâye haritası tekniğinin okuduğunu anlamaya etkisinin değerlendirilmesi. Milli Ĕgitim Dergisi, 49(228), 241-261.

Dermitzaki, I., Andreou, G. ve Paraskeva, V. (2008). High and low reading comprehension achievers' strategic behaviors and their relation to performance in a reading comprehension situation. Reading Psychology, 29(6), 471-492.

Duke, N. K. ve Pearson, P. D. (2008). Effective practices for developing reading comprehension. The Journal of Education, 189(1/2), 107-122.

Elbro, C. ve Petersen, D. K. (2004). Long term effects of phoneme awareness and letter sound training: An intervention study with children at risk for dyslexia. Journal of Educational Psychology, 96, 660-670.

Entwisle, D. R., Alexander, K. L. ve Olson, S. (2005). First grade and educational attainment by age 22: A new story. American Journal of Sociology, 110, 1458-1502.

Firat, T. (2019). Effects of the TWA strategy instruction on reading comprehension of students with learning disabilities. Educational Research Quarterly, 43(2), 24-54.

Fırat, T. ve Ergül, C. (2020). 3D strateji öğretiminin öğrenme güçlüğü olan öğrencilerin bilişsel ve üstbilişsel stratejileri kazanmalarına etkisi. Kastamonu Eğitim Dergisi, 28(3), 13901406.

Fisher, W., Kelley, M. ve Lomas, J. (2003). Visual aids and structured criteria for improving visual inspection and interpretation of single-case designs. Journal of Applied Behavior Analysis, 36, 387-406. 
Forness, S. R., Kavale, K. A., Blum, I. M. ve Lloyd, J. W. (1997). Mega-analysis of metaanalyses: What works in special education and related services. Teaching Exceptional Children, 29(6), 4.

Gajria, M., Jitendra, A. K., Sood, S. ve Sacks, G. (2007). Improving comprehension of expository text in students with LD: A research synthesis. Journal of Learning Disabilities, 40(3), 210-225.

Gersten, R., Fuchs, L. S., Compton, D., Coyne, M., Greenwood, C. ve Innocenti, M. S. (2005). Quality indicators for group experimental and quasi-experimental research in special education. Exceptional Children, 71, 149-164.

Gersten, R., Fuchs, L., Williams, J. P. ve Baker, S. (2001). Teaching reading comprehension strategies to students with learning disabilities. Review of Educational Research, 71(2), 279-320.

Girli, A. ve Öztürk, H. (2017). Metacognitive reading strategies in learning disability: Relations between usage level, academic self-efficacy and self-concept. International Electronic Journal of Elementary Education, 10(1), 93-102.

Gottfried, A. E. (1990). Academic intrinsic motivation in young elementary school children. Journal of Educational Psychology, 82, 525-538.

Grabe, W. ve Stoller, F. (2002). Teaching and research reading. Harlow, UK: Longman.

Graham, L. (2006). Strategy instruction and the teaching of writing: A meta-analysis. In C. A. MacArthur, S.. Graham, \& J. Fitzgerald (Eds.), Handbook of writing research (pp. 187207). New York: Guilford Press.

Graham, L. ve Bellert, A. (2005). Reading comprehension difficulties experienced by students with learning disabilities. Australian Journal of Learning Difficulties, 10(2), 71-78.

Graham, S. ve Harris, K. R. (2003). Students with learning disabilities and the process of writing: A meta-analysis of SRSD studies. In L. Swanson, K. R. Harris \& Graham (Eds.), Handbook of research on learning disabilities (pp, 383-402). New York, NY: Guilford.

Graham, S. ve Harris, K. R. (2005). Writing better: Effective strategies for teaching students with learning disabilities. Baltimore, MD: Paul H. Brookes.

Graham, S., Harris, K. R., Macarthur, C. A. ve Schwartz, S. (1991). Writing and writing instruction for students with learning disabilities: Review of a research program. Learning Disability Quarterly, 14(2), 89-114.

Güldenoğlu, İ. B. ve Kargın, T. (2012). Karş1lıklı öğretim tekniğinin hafif derecede zihin engelli öğrencilere okuduğunu anlama becerilerinin öğretiminde etkililiğinin ve sürekliliğinin incelenmesi. Ankara Üniversitesi Eğitim Bilimleri Fakültesi Özel Eğitim Dergisi, 13(1), 17-34.

Güler, Ö. ve Özmen, R. G. (2010). Using the brief experimental analysis to determine the effective reading comprehension strategy in story comprehension of students with mental retardation (Electronic version). International Online Journal of Educational Sciences, 2(3), 930-954.

Hedin, L., Mason, L. H. ve Gaffney, J. (2011). TWA plus prompted discourse: Reading comprehension effects for three students with learning disabilities. Preventing School Failure, 55, 148-157.

Horner, R. H., Carr, E. G., Halle, J., McGee, G., Odom, S. ve Wolery, M. (2005). The use of single-subject research to identify evidence-based practice in special education. Exceptional Children, 71(2), 165-179. 
House, A. E., House, B. G. ve Campbell, M. B. (1981). Measures of Interobserver Agreement: Calculation Formula and Distribution Effect. Journal of Behavioral Assessment, 3(1), 3757.

Hulme, C. ve Snowling, M. J. (2011). Children's reading comprehension difficulties: Nature, causes, and treatments. Current Directions in Psychological Science, 20, 139-142.

İlter, İ. (2018). Zayıf okuyucuların okuduğunu anlama becerilerinin geliştirilmesinde ana fikir belirleme becerisinin öğretimi. Ankara Üniversitesi Eğitim Bilimleri Fakültesi Özel Eğitim Dergisi, 19(2), 303-334. doi: 10.21565/ozelegitimdergisi.315887

Jitendra, A. K., Cole, C. L., Hoppes, M. K. ve Wilson, B. (1998). Effects of a direct instruction main idea summarization program and self-monitoring on reading comprehension of middle school students with learning disabilities. Reading \& Writing Quarterly: Overcoming Learning Difficulties, 14(4), 379-396.

Jitendra, A. K., Hoppes, M. K. ve Xin, Y. P. (2000). Enhancing main idea comprehension for students with learning problems: The role of a summarization strategy and self-monitoring instruction. The Journal of Special Education, 34(3), 127-139.

Johnson, L, Graham, S. ve Harris, K. (1997). The effects of goal setting and self-instruction on learning a reading comprehension strategy: a study of students with learning disabilities. Journal of Learning Disabilities, 30, 80-91.

Johnson, J. W., Reid, R. ve Mason, L. H. (2011). Improving the reading recall of high school students with ADHD. Remedial and Special Education, 33(4), 258-268.

Jones, A. G. (2010). The effects of duet reading on the reading fluency and comprehension of high school students with learning disabilities (Doctoral Dissertation). Available from ProQuest Dissertations and Theses database. (UMI No. 3434146)

Kamil, M. L. (2003). Adolescents and literacy: Reading for the $21^{s t}$ Century. Washington DC: Alliance for Excellent Education.

Kendeou, P., Papadopoulos, T. C. ve Spanoudis, G. (2012). Processing demands of reading comprehension tests in young readers. Learning and Instruction, 22(5), 354-367.

Kendeou, P. ve Trevors, G. (2012). Learning from texts we read: What does it take. In M. J. Lawson \& J. R. Kirby (Eds.), The quality of learning, (pp. 251-275). Cambridge, UK: Cambridge University Press.

Kendeou, P., van den Broek, P. Helder, A. ve Karlsson, J. (2014). A cognitive view of reading comprehension: Implications for reading difficulties. Learning Disabilities Research \& Practice, 29(1), 10-16.

Kim, W., Linan-Thompson, S. ve Misquitta, R. (2012). Critical factors in reading comprehension instruction for students with learning disabilities: A research synthesis. Learning Disabilities Research \& Practice, 27(2), 66-78.

Kirby, J. R. ve Savage, R. S. (2008). Can the simple view deal with the complexities of reading? Literacy, 42, 75-82.

Kratochwill, T. R., Hitchcock, J., Horner, R. H., Levin, J. R., Odom, S. L., Rindskopf, D. M ve Shadish, W. R. (2010). Single-case designs technical documentation. What Works Clearinghouse. Retrived from http://ies.ed.gov/ncee/wwc/pdf/wwc_scd.pdf.

Kucan, L. ve Beck, I. L. (2003). Inviting students to talk about expository texts: A comparison of two discourse environments and their effects on comprehension. Literacy Research and Instruction, 42(3), 1-31.

Lederer, J. M. (2000). Reciprocal teaching of social studies in inclusive elementary classrooms. Journal of Learning Disabilities, 33, 91-106. 
Luna, B., Garver, K. E., Urban, T. A., Lazar, N. A. ve Sweeney, J. A. (2004). Maturation of cognitive processes from late childhood to adulthood. Child Development, 75(5), 13571372.

Lyon, G. R. (1998). Overview of reading and literacy initiatives. Washington, DC: National Institute of Child Health and Human Development.

Mahdavi, J. N. ve Tensfeldt, L. (2013). Untangling reading comprehension strategy instruction: Assisting struggling readers in the primary grades. Preventing School Failure: Alternative Education for Children and Youth, 57(2), 77-92.

Malone, L. ve Mastropieri, M. A. (1992). Reading comprehension instruction: Summarization and self-monitoring training for students with learning disabilities. Exceptional Children, $21,270-279$.

Mason, L. H. (2004). Explicit self-regulated strategy development versus reciprocal questioning: Effect on expository reading comprehension among struggling readers. Journal of Educational Psychology, 96, 283-296.

Mason, L. H., Harris, K. R. ve Graham, S. (2013). Strategies for improving student outcomes in written expression. In M. Tankersly \& B. Cook (Eds.), Effective practices in special education (pp. 86-97). Upper Saddle River, NJ: Pearson.

Mason, L. H., Hickey Snyder, K., Jones, D. P. ve Kedem, Y. (2016). TWA + PLANS Strategies for expository reading and writing: Effects for nine 4th-grade students. Exceptional Children, 73(1), 69-9.

Mason, L. H., Meadan-Kaplansky, H., Hedin, L. ve Corso, L. (2006). Self-regulated strategy development instruction for expository text comprehension. Teaching Exceptional Children, 38, 47-52.

Nation, K. (2005). Children's reading comprehension difficulties. In M. J. Snowling \& C. Hulme (Eds.), The science of reading: A handbook (pp. 248-266). Oxford, UK: Blackwell.

Özbek, A. B. (2019). Öğrenme güçlüğ̈̈ olan öğrencilerde strateji öğretimi yazılımının okuduğunu anlama becerilerinin geliştirilmesine etkisi (Yayınlanmamış Doktora Tezi). Ankara Üniversitesi Eğitim Bilimleri Enstitüsü. Ankara.

Özdemir, Y. (2017). Okumadan önce, okuma esnasinda, okumadan sonra düşün” stratejisinin okuduğunu anlama becerisine etkisi (Yayınlanmamış Doktora Tezi) Ondokuz Mayıs Üniversitesi, Eğitim Bilimleri Enstitüsü. Samsun.

Partanen, M. ve Siegel, L. S. (2014). Long-term outcome of the early identification and intervention of reading disabilities. Reading and Writing, 27(4), 665-684.

Perfetti, C. A. ve Hart, L. (2001). The lexical basis of comprehension skill. In D. S. Gorfein (Ed.), Decade of behavior. On the consequences of meaning selection: Perspectives on resolving lexical ambiguity (pp. 67-86). American Psychological Association.

Pressley, M. ve Hilden, K. (2005). Towards more ambitious comprehension instruction. In E. R. Silliman \& L. C. Wilkinson (Eds.), Language and literacy learning in schools (pp. 151174). New York: Guilford.

Rogevich, M. E. ve Perin, D. (2008). Effects on science summarization of a reading comprehension intervention for adolescents with behavior and attention disorders. Exceptional Children, $74,135-154$.

Scarborough, H. S. (1998). Early identification of children at risk for reading disabilities: Phonological awareness and some other promising predictors. Specific reading disability: $A$ view of the spectrum, 10(2), 75-119. 
Scharlach, T. D. (2008). START comprehending: Students and teachers actively reading text. The Reading Teacher, 62(1), 20-31.

Schultz, G. E. ve Switzky, H. N. (1993). The academic achievement of elementary and junior high school students with behavioral disorders and their non-handicapped peers as a function of motivational orientation. Learning and Individual Differences, 5, 31-42.

Sesma, H. W., Mahone, E. M., Levine, T., Eason, S. H. ve Cutting, L. E. (2009). The contribution of executive skills to reading comprehension. Child Neuropsychology, 15(3), 232-246.

Simmons, D. C., Coyne, M. D., Kwok, O. M., McDonagh, S., Harn, B. A. ve Kame'enui, E. J. (2008). Indexing response to intervention: A longitudinal study of reading risk from kindergarten through third grade. Journal of Learning Disabilities, 41(2), 158-173.

Swanson, H. L. (1999). Reading research for students with LD: A meta-analysis of intervention outcomes. Journal of Learning Disabilities, 32, 504-532.

Torppa, M., Georgiou, G. K., Lerkkanen, M. K., Niemi, P., Poikkeus, A. M. ve Nurmi, J. E. (2016). Examining the simple view of reading in a transparent orthography: A longitudinal study from kindergarten to grade 3. Merrill-Palmer Quarterly (1982-), 62(2), 179-206.

Tunmer, W. E. (2008). Recent developments in reading intervention research: Introduction to the special issue. Reading and Writing: An Interdisciplinary Journal, 21(4), 299-316.

Uçar-Rasmussen, M. ve Cora-İnce, N. (2017). Özel öğrenme güçlüğü olan bireylere üstbilişsel okuduğunu anlama stratejilerinin öğretiminde sesli düşünme yönteminin etkililiği. Abant İzzet Baysal Üniversitesi Ë̆itim Fakültesi Dergisi, 17 (4), 2180-2201.

van den Broek, P. ve Kremer, K. E. (1999). The mind in action: What it means to comprehend during reading. In B. Taylor, M. Graves, \& P. van den Broek (Eds.), Reading for meaning (pp. 1-31). New York: Teacher's College Press.

van den Broek, P., Lorch, R. F., Jr., Linderholm, T. ve Gustafson, M. (2001). The effects of readers' goals on inference generation and memory for texts. Memory \& Cognition, 29(8), 1081-1087.

Wanzek, J., Vaughn, S., Scammacca, N. K., Metz, K., Murray, C. S., Roberts, G. ve Danielson, L., (2013). Extensive reading interventions for students with reading difficulties after grade 3. Review of Education Research, 83, 163-195.

Watson, S. M., Gable, R. A., Gear, S. B. ve Hughes, K. C. (2012). Evidence-based strategies for improving the reading comprehension of secondary students: implications for students with learning disabilities. Learning Disabilities Research \& Practice, 27(2), 79-89.

Williams, J. P. ve Atkins, J. G. (2009). The role of metacognition in teaching reading comprehension to primary students. In D. J. Hacker, J. Dunlosky, \& A. C. Graesser (Eds.), Handbook of metacognition in education (pp. 26-43). New York, NY: Routledge.

Winograd, P. N. (1983). Strategic difficulties in summarizing texts. Technical Report No. 274. Retrieved from http://files.eric.ed.gov/fulltext/ED228616.pdf

Wolf, M. (1997). A provisional, integrative account of phonological and naming-speed deficits in dyslexia: Implications for diagnosis and intervention. In B. A. Blachman (Ed.), Foundations of reading acquisition and dyslexia: Implications for early intervention (pp. 67-92). Lawrence Erlbaum Associates Publishers.

Wong, B. (Ed.). (2011). Learning about learning disabilities. Academic Press. 


\section{EK 1. Metni Anlatma Puanlama Anahtarı}

\section{Denek:}

Metin:

\begin{tabular}{|c|c|c|c|c|c|}
\hline & 4 & 3 & 2 & 1 & Puan \\
\hline Bilgi Birim & $\begin{array}{l}\text { Metinde yer alan } \\
\text { bilgi birimlerinin } \\
15-19 \text { tanesini } \\
\text { anlatır }\end{array}$ & $\begin{array}{l}\text { Metinde yer } \\
\text { alan bilgi } \\
\text { birimlerinin 11- } \\
14 \text { tanesini } \\
\text { anlatır }\end{array}$ & $\begin{array}{l}\text { Metinde yer } \\
\text { alan bilgi } \\
\text { birimlerinin 7- } \\
10 \text { tanesini } \\
\text { anlatır }\end{array}$ & $\begin{array}{l}\text { Metinde yer alan } \\
\text { bilgi birimlerinin } 6 \\
\text { ya da daha azını } \\
\text { anlatır }\end{array}$ & \\
\hline Doğruluk & $\begin{array}{l}\text { Aktardığı bilgi } \\
\text { birimlerinin } \\
\text { tamamı doğrudur }\end{array}$ & $\begin{array}{l}\text { Aktardığı bilgi } \\
\text { birimleri } \\
\text { çoğunlukla } \\
\text { doğrudur }\end{array}$ & $\begin{array}{l}\text { Aktardığı bilgi } \\
\text { birimleri kısmen } \\
\text { doğrudur }\end{array}$ & $\begin{array}{l}\text { Aktardığ bilgi } \\
\text { birimleri yanlıştır }\end{array}$ & \\
\hline $\begin{array}{l}\text { Cümle } \\
\text { Yapısı }\end{array}$ & $\begin{array}{l}\text { Anlamlı ve farklı } \\
\text { yapıda cümleler } \\
\text { söyler }\end{array}$ & $\begin{array}{l}\text { Çoğunlukla } \\
\text { anlamlı ve farklı } \\
\text { yapıda cümleler } \\
\text { söyler }\end{array}$ & $\begin{array}{l}\text { Çoğunlukla } \\
\text { anlamlı ve } \\
\text { benzer yapıda } \\
\text { cümleler söyler }\end{array}$ & $\begin{array}{l}\text { Anlamsız ve } \\
\text { benzer yapıda } \\
\text { cümleler söyler }\end{array}$ & \\
\hline $\begin{array}{l}\text { Bilgi } \\
\text { Düzenleme }\end{array}$ & $\begin{array}{l}\text { Çoğunlukla } \\
\text { cümleleri } \\
\text { birbiriyle } \\
\text { ilişkilendirerek } \\
\text { ve metindeki } \\
\text { sirayı izleyerek } \\
\text { ifade eder }\end{array}$ & $\begin{array}{l}\text { Kısmen } \\
\text { cümleleri } \\
\text { birbiriyle } \\
\text { ilişkilendirerek } \\
\text { ve metindeki } \\
\text { sırayı izleyerek } \\
\text { ifade eder }\end{array}$ & $\begin{array}{l}\text { Nadiren } \\
\text { cümleleri } \\
\text { birbiriyle } \\
\text { ilişkilendirerek } \\
\text { ve metindeki } \\
\text { sirayı izleyerek } \\
\text { ifade eder }\end{array}$ & $\begin{array}{l}\text { Cümleleri } \\
\text { birbiriyle } \\
\text { ilişkilendirmeden } \\
\text { metindeki sırayı } \\
\text { izlemeden söyler }\end{array}$ & \\
\hline
\end{tabular}

Toplam

\section{Kullanım Yönergesi}

- Öğrencinin aktardığı anlamlı bütünlük gösteren söz grupları bilgi birimi olarak kabul edilir. Bilgi birimi tek bir cümle olabileceği gibi birden çok cümle ile de ifade edilmiş olabilir.

- Bilgi birim maddesi öğrencinin aktardığı bilgi birimlerinden metinde yer alanlar sayılarak değerlendirilir.

- Doğruluk maddesi öğrencinin aktardığı bilgi birimlerinin ilgili metinde yer alan bilgi birimleri ile olan uyuşma düzeyi belirlenerek puanlanır.

- Cümle yapısı maddesi öğrencilerin oluşturdukları cümlelerin sentaks, semantik ve morfolojik olarak değerlendirilmesi sonucu belirlenir. Metindeki bilgi birimlerine yönelik olup olmadığından bağımsız olarak değerlendirilir.

- Bilgi düzenleme maddesi öğrencinin aktardığı bilgi birimlerini metindeki sırayı takip ederek aktarması ve bilgi birimleri arasındaki ilişkileri yansıtması göz önünde bulundurularak puanlanır.

\section{EXTENDED ABSTRACT}

\section{Introduction}

Reading is a skill that requires fluency in decoding, adequate vocabulary and comprehension of sentences and texts (Jones, 2010). Grabe and Stoller (2002) defined reading comprehension as a high-level skill that involves complex, rapid, and many cognitive processes. Some students do not always manage this process well, they have problems with one or more of these components and have difficulty understanding what they read (Tunmer, 2008). These students are often diagnosed with learning disabilities or they have reading difficulties throughout their academic life (Lyon, 1998). 
In many studies it is seen that students with learning disabilities use less comprehension strategies than their typically developing peers and their knowledge about use of reading comprehension strategies are very limited (Dermitzaki et al., 2008). Because of that, strategy instruction towards reading comprehension skills of students with LD is a frequently examined topic. One of the well-known strategy intervention is Think-Befor-While-After, TWA (Baker, Gertsen \& Scanlon, 2002). TWA is a multicomponent strategy intervention involves nine steps for developing reading comprehension performances. Self-regulation strategies development SRSD strategy instruction model is a widely used framework and presents pathway for strategy interventions.

However strategy instruction is frequently examined in international literature, there are few studies in Turkey. In national literature there are studies conducted with typically developing students (Coşkun, 2011; Özdemir, 2017), with intellectual disabilities (Cora-İnce, 2007; Duman, 2006; Güldenoğlu \& Kargın, 2012). There is only one study in Turkish literature (Firat, 2017) examining the effectiveness of strategy instruction on reading comprehension skills of students with LD. It is clear that there is a need for new studies on developing reading comprehension performances of students with LD. Aim of this study is examining effectiveness of TWA strategy instruction on comprehension performances of students with LD.

\section{Method}

\section{Participants}

Four $4^{\text {th }}$ grade students with learning disability participated in the study. All of these students are children who have been diagnosed with learning disabilities, continue to the fourth grade, no grade repetition, have no comorbidities, haven't received strategy instruction before, and have at least 45 words reading fluency over $\% 90$ accuracy.

\section{Dependent Variable}

Multiple choice test and retell scores of students are the independent variables of the study.

\section{Independent Variable}

TWA strategy intervention according to SRSD instruction framework is the independent variable of the study.

\section{Data Collection}

Data collection process was completed in September and October, at the beginning of 2019-2020 education. For this purpose, 12 intervention sessions were held in four weeks, with three sessions per week with all students. The intervention sessions lasted on average 30-35 minutes. Total of 10 intervention session data were collected.

Baseline Sessions: In the baseline assessments, students were asked read the texts twice (aloud and silent) then answer the multiple choice test and retell what they learned from the text they read. After one baseline session was held with all students, four more assessment sessions were held with the first participant and the intervention phase was started.

Intervention Sessions: The SRSD framework consists of six steps as follows: Activating prior knowledge, discussion, modeling, memorizing, supporting and independent practice. During the activating of prior knowledge sessions, students were asked what they did to understand better and remember what they read. During the discussion phase, the TWA strategy and the hint card were introduced to the students by talking about what we do and what else we can do to comprehend a text better. During the modeling phase, researcher presented a model by applying the strategy steps before, during and after reading as he reads his own text. For memorization step students were asked to practice and learn the strategy steps with the hint card at the end of all modeling sessions. During the support phase, the researcher continued strategy instruction by withdrawing the tips and reducing the support given to the student. Finally, students 
were asked to read and respond to the test using strategies only by giving texts during the independent practices phase. Follow-up sessions took place on the 7th, 14th and 21st days after the intervention sessions.

\section{Procedural Fidelity and Inter Observer Reliability}

Procedural fidelity of the study was evaluated by $30 \%$ of the audio recordings taken during the sessions and it was determined that the procedural fidelity is $98 \%$. Inter-observer reliability of the study is calculated as $92 \%$.

\section{Results}

In the intervention sessions, it is seen that the average of the participants' multiple choice test and retell scores are increased. In the follow-up sessions, it is seen that the scores of all participants showed a small decrease compared to the intervention sessions, but they were still above the baseline. Finding are shown in Graph 1 and Graph 2 and Table 1.

Percentage of non-overlapping data of multiple choice test and retell scores for all participants were calculated as $100 \%$. On the other hand when Graph 1 and Graph 2 visually analyzed it is clear that independent variable has immediacy effect on dependent variables.

\section{Discussion and Conclusion}

In this study, it was aimed to develop reading comprehension skills of four students with learning disabilities with 3D strategy instruction conducted according to SRSD model. In intervention sessions, comprehension performances of all four students increased and their average scores are meaningfully above baseline. In the follow-up sessions, although the reading comprehension performances of the students decreased slightly, all participants performed well above their baseline scores. The contribution of 3D strategy instruction to students' reading comprehension and academic skills has been shown in many studies (Graham, 2006; Johnson et al., 1997; Johnson, Reid, \& Mason, 2011; Mason, 2004; Mason, 2013). In this context, the results obtained from this research are compatible with the literature. Strategy instruction is an effective way to develop reading comprehension and should be used by teachers who work with students with LD. 